\title{
Greek Mythology at the Service of the Portuguese Inquisition: The Case of Hercules and the Hydra of Lerna
}

\author{
By Milton Dias Pacheco*
}

Greek mythology has been along the centuries a fruitful source of inspiration to artists and writers, as it possesses the strength of expressing symbolically the most common circumstances of life. Regarding the threats that in every age put in danger human life the most popular figure was maybe the Hydra that infested the region of the Lake of Lerna, in Argolis. This mythical figure may still have an older origin as it is connected with chthonic dangers. Because of its terrifying aspect, reptilian traits and poisonous breath, it was related to the evil and the domains of Hell. Later the Hydra significance became larger and deeper as it represented the heresies that could affect the Christian orthodoxy. According to this point of view, every defender of the Catholic Faith was immediately compared to Hercules, the Greek hero who succeeded in killing the mythological Hydra monster. In this way, it is easy to understand why this representation was often used in connection with the Iberian Habsburg Kings, as it worked as a political strategy of this dynasty, in which the Spanish Habsburgs were faced as the guardians and defenders of the Church of Rome, mainly in times when the Inquisition developed a determinative role. An illustrative example of this was the decoration of the arch built by the Inquisition in Lisbon, when King Philip II of Portugal visited the Portuguese Empire capital. There, allegorical compositions could be seen, exploring the symbolism of the defeat of the Hydra, in a clear allusion to the decisive role fulfilled by Inquisition and the King himself. Thus, within the evolution of the symbolic load of this myth in the Mediterranean basin has to take into account the Christianization of it in the European southern countries emphasizing its religious allegorical meaning.

Born nearby the Mediterranean Sea, the cradle of European Civilization, the Greek legacy has influenced for the last two millenniums and half the entire Western culture. One of the most famous legacies is the primitive Greek religion, disseminated for all Mediterranean by the Roman Empire, which results afterwards in an unprecedented cultural flourishing expansion during the Renaissance. For centuries the architects, sculptors, painters, writers and

${ }^{*}$ PhD Student, Coimbra University, Portugal. 
philosophers worked not only on concepts of beauty, goodness and justice but also ugliness, evil and iniquity under the sign of the Greek Mythology.

Influenced by the greatest historical moments represented in classical Art, emperors, kings, princes, and sometimes even popes and bishops, have sought to exalt their own figures and reinforce their own political authority and military skills, kingship and eloquence, throughout the appropriation of powerful gods, great kings and epic heroes features. They have been since ever a fruitful source of inspiration especially because they possess the strength of expressing the most common circumstances of the human condition, not only the virtues and aspirations but also the vices and fears.

Among the numerous European Royal Houses that used the ancient Greek mythology in their propaganda policy and to reinforce pompously their own image during the Early Modern Period was the Spanish Habsburg House. As the result of an ingenious matrimonial alliance, Charles of Ghent [1500-1558] would become the ruler of several European kingdoms: the Duchy of Burgundy and the Burgundian Netherlands; the Spanish Kingdom, which included the Italian states of Naples, Milan, Sardinia and Sicily; and finally the Holy Roman Empire.

If we analyze some symbols used by Charles I of Spain we can find, for instance, an exceptional relation between the Spanish monarchs and the Greek hero Heracles. The son of Zeus and Alcmene, better known by his Roman name Hercules, was considered the mythical founder of the Spanish Monarchy ${ }^{1}$ (Morford \& Lenardon, 2003, 519-521; Rodrigues, 2011, 11), a European western kingdom where he executes one of his twelve labors.

In Charles I's coat of arms, later integrated in the flag of Spain, were used the Pillars of Hercules, representation of the Strait of Gibraltar opened after the split of the rocks of Calpe, in Gibraltar, and Abyla, in Ceuta (Lavanha, 1622, $39 \mathrm{v}$ ). Moreover, the motto "PLUS ULTRA" would be the indicator of the Emperor's enterprise over the new American overseas possessions ${ }^{2}$.

Besides Hercules, there was another Greek mythological hero used in the royal propaganda strategy - Jason, the leader of the Argonauts. To represent the Order of the Golden Fleece, established in 1430 by Philip the Good [14191467] and later inherited by the German Emperor, the members used the insignia of the fleece rescued by Jason, helped by Hercules and the Argonauts, in order to reclaim rightfully the throne of Iolcus.

Hercules, the most important and popular Greek heroic figure with a superhuman strength that permitted him to ensure amazing works and defeat terrible monsters, has in his mythological biography traits which allowed the expression of ideals of political power, dominance and grandeur. Among the

\footnotetext{
${ }^{1}$ In Cádiz the Hercules Tower celebrates the passage of the hero by Spain.

${ }^{2}$ During the reception organized in the Palace of Fontainebleau, in 1540, Charles I received from the French King as a gift a statue of Hercules, which reveals how Hercules figure was associated to him. His successor, King Philip I of Portugal/II of Spain, would use Hercules figure to reinforce his own royal image, when he ordered a self-portrait on the roof of the Lisbon Royal Palace. Actually the king already used the mythological heroic themes to represent himself in the portraits ordered to Titian thirty years before (Huon, 1956, 23; Morford \& Lenardon, 2003, 527; Pacheco,2011, 9).
} 
countless episodes explored by the classical authors and later used by several European monarchs and politicians is highlighted the fight of Hercules against the Hydra of Lerna. Throughout effective propaganda mechanisms they introduce themselves to their own people as heroes, as their faithful defenders against the most terrible enemies ${ }^{1}$. On the other hand, Hercule's dreadful foes were chosen to represent their political adversaries and religious opponents.

For instance, the French King Henry IV $^{2}$ [1553|1589-1610] was painted in the beginnings of the seventeenth century as Hercules slaying the Hydra (Fig. 1) with the scope of show his triumph over the Catholic Holy League and the end of the religious wars in France ${ }^{3}$. Another identical representation of Henry IV evoked as the Gallic Hercules, crushing again the Hydra monster, was used to adorn the ephemeral arches erected for the solemn royal entry in Lyon, in 1595, and later in Avignon, in 1600. And yet, in 1592 he was represented in a medal again as Henry-Hercules, dragging the imprisoned Cerberus from the Underworld ${ }^{4}$.

Additionally, in the late eighteenth century, the Portuguese House of Braganza adopted also the Hercules fighting the Hydra imagery to represent the monarch D. Joseph [1714|1750-1777].

Despite the use of the Portuguese sculptor Joaquim Machado de Castro [1731-1822], when he conceived the royal equestrian statue, of simple snakes ${ }^{5}$, over some thorns, to exemplify the King's political enemies and material difficulties during the reconstruction of the city of Lisbon, after the 1755 earthquake, an engrave that illustrates the expulsion of the Jesuits from Portugal, in 1759, presents intentionally the King dressed as Hercules defeating a Jesuit-Hydra, where each snake has a biretta in the head (Soares, 1948, 244) ${ }^{6}$.

\footnotetext{
${ }^{1}$ Corrado Vivanti defended that the "Ancient heroes had earned immortality by freeing their people from monsters and fearful beasts" (Vivanti, 1967, 182).

${ }^{2} \mathrm{He}$ was King Henry II's grandson, the king who was represented at Saint Denis gate, in Paris, in 1549, as the Hercule Gaulois (Jacquot, 1956, 12).

${ }^{3}$ The painting, executed in the circle of Toussaint Dubreuil c.1600, is in Louvre Museum, Paris. ${ }^{4}$ Actually, it was not only Hercules, one of the king's favorite figures, but many others ancient epic warriors and military commanders; hence he was "often portrayed as one of the most famous figures of ancient times, from Alexander to Caesar, from Augustus to Constantine, from David to Charlemagne" (Vivanti, 1967, 182-186).

${ }^{5}$ The sculptor in his equestrian statue description quotes the Venetian edition of Cesar Ripa's Iconologia, 1669: "Pligiansi anco il serpente per figura universali d'ogni peccato es vitio". (Castro 1810, 272).

${ }^{6}$ Executed by Montalais, the engrave was published within the anti-Jesuit work, Recueil de figures historiques, symboliques, et tragiques pour server à l' histoire du XVIII siècle, in 1762, in Amsterdam, under the title "Cunarum labor est angues superare mearum", from Ovid (Metamorphosis: IX, 67). It is possible to find this engrave at the collections of the Biblioteque Nationale de Paris, France, under the title "Complots et Attentats des Jésuites contre la Sacrée personne du Roy de Portugal". We would like to express our gratitude to Filipa Medeiros for this information and access to her essay in process of publication. In the same period, in 1775, it was published the Ad monvmentvm aeternvm divi Iosepho I presenting D. Joseph as Hercules crushing two snakes (also the Jesuits according to Ernesto Soares) with a mace and helping to rise the allegoric figure of Lisbon, carrying in her hand the royal equestrian statue model. A copy of this engrave, executed by Eleutério Manuel de Barros according to Joaquim Carneiro da Silva's drawing, is deposited in the Biblioteca Nacional de Portugal, in Lisbon (Medeiros $[2013,1,5-7])$.
} 
Vol. 1, No. $1 \quad$ Pacheco: Greek Mythology at the Service of the Portuguese...

Figure 1. Henry IV of France as Hercules Slaying the Lernean Hydra

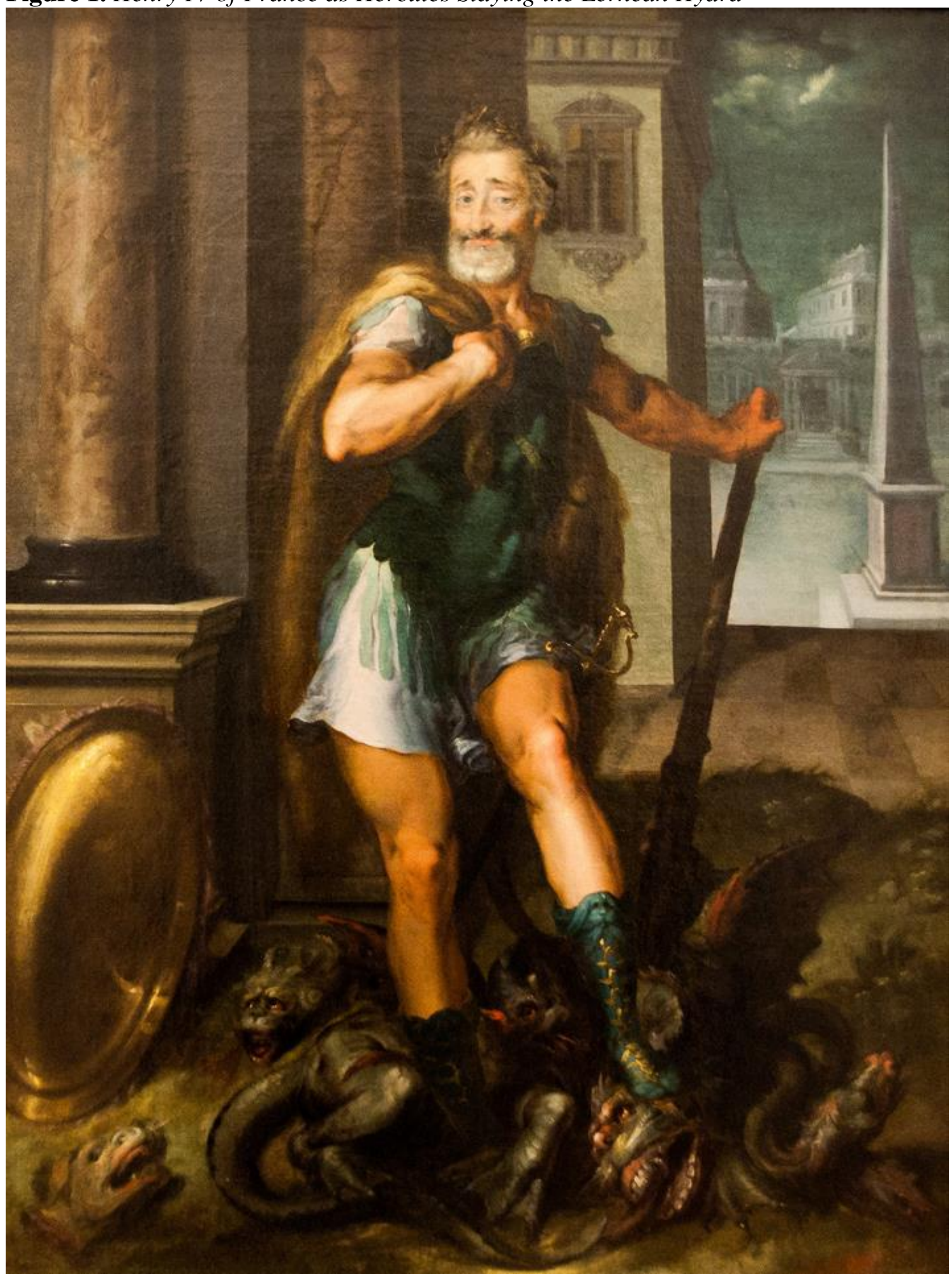

Source: Circle of Toussaint Dubreuil, Circa 1600, Oil on canvas, Musée du Louvre, Paris, France 
Meanwhile, in the nineteenth century, it seems to be common in the Londoner political circles the use of the Hercules and the Hydra figures to criticize the opposition. The first example, a hand-colored etching dated from 1831, shows a politician, dressed and armed like Hercules, decapitating in a guillotine his opponents, represented as the seven-headed Hydra monster (Fig. 2).

The other one is a study for a satirical print, probably executed by the cartoonist John Doyle [1797-1868] in 1844, for the series Political Sketches, that represents Wellington as Hercules assisted by Brougham, as Iolaus, fighting the East India Company directors, each one represented in a head of the Hydra ${ }^{1}$.

Our last example, chosen among many others, is the painting of Hercules and the Lernaean Hydra, executed around 1875-76 by Gustave Moreau [18261898 ] to express the political tension between France and Germany at the time (Blázquez, 2000, 261).

Figure 2. "Hercules Decapitating the Hydra"

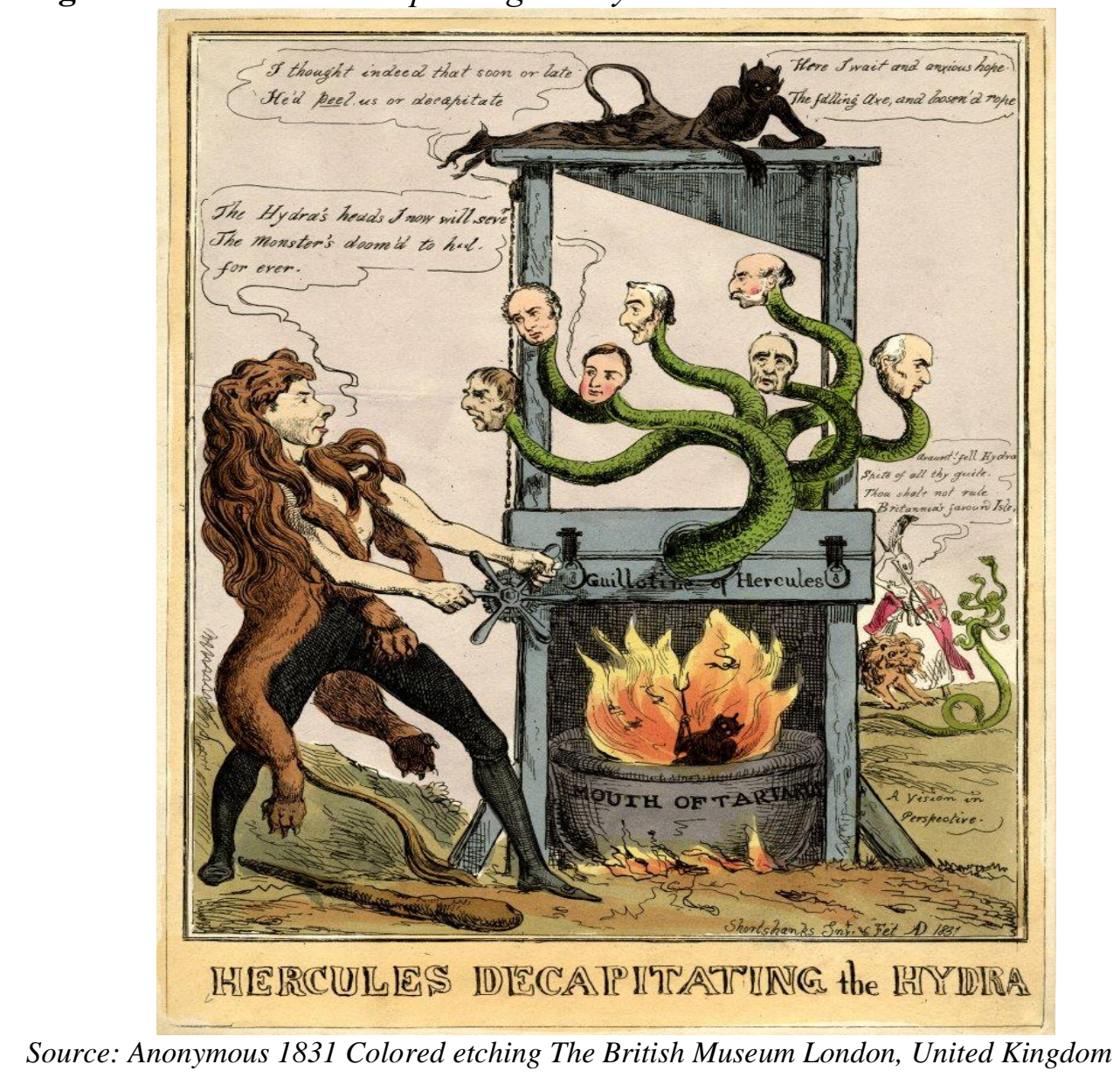

\footnotetext{
${ }^{1}$ Both images belong to the British Museum collections.
} 
The majority of artistic programs of the Modern entrées triomphales royales have not eliminated the use of biblical characters to represent the monarch's figures, despite the clear preference to mythical ones: "Ceci ne veut pas dire que l'entrée se paganise, mais la religion chrétienne elle-même y paraît vêtue à l'antique. L'évolution, d'ailleurs, est progressive; on sait que les histoires de Troie, les légendes d'Hercule et de Jason facilitent le passage d'un décor de fête dont l'art est encore tout médiéval à un décor créé par des artistes s'inspirant de l'architecture et de la statuaire antique" (Jacquot 1956, 11-12) ${ }^{1}$.

Since the first moments of the Renaissance, the Church of Rome allowed artists and poets to portray the major Greek mythology themes alongside with the traditional Christian subjects. Actually, the patristic texts and the art of the early Christian times proved an effective contamination of the classical myths even after the triumph of Christianity.

Besides the written descriptions of Christ defeating Hades/Death and His conquest over the Underworld/Hell after the crucifixion, there is still in the Roman catacombs, beneath Saint Peter's Basilica, a wall mosaic showing Christ as sun-god ascending in the chariot of the sun, imitating god Apollo. And curiously, in the same catacombs is found a fourth century fresco showing Hercules slaughtering the Hydra (Frazer, 1974, 157-158; Morford \& Lenardon, 2003, 694).

And if the testimony of Ephraem the Syrian [?-378] mentioned that Christ "tore apart the voracious stomach of Hades and blocked the treacherous fully opened jaws of Satan", the sermon attributed to Saint John Chrysostom [c. 347407] points out the killing of the "the infernal serpent" and one of the hymns of Romanos the Melodist [6th century] mentioned the "snake, evil counselor, three-headed dragon". As Margaret Frazer [20th century] also refers, the episode of Hercules drawing Cerberus out of the Underworld was Christianized and adapted to Christ pulling Adam from Hell (Frazer, 1974, 157-161).

If we analyze Hercules biography under a religious point of view, in a process of interpretatio christiana, it is possible to draw assimilation parallels of some glorious deeds of the hero with the actions executed by Christian martyrs and saints later on.

For instance, artists depurated the profane signs with the purpose of christianizing them in an ingenious way, despite some authors, like Torquato Tasso [1544-1595], in Discorsi dell'Arte Poetica, 1564, that recommends the use of Christian sources instead the dangerous and pagan ones.

The famous labors (or penances?) of Hercules were delivered to him by the sacred Delphic Pythoness. This assignment, truly herculean, should serve not only to the hero self-punishment, for the wife and children murdered by his own hands, but also it was the only way to achieve immortality, as the Oracle of Delphos had predicted (Morford \& Lenardon, 2003, 522). Redemption and everlasting life are still two concepts so closely connected to the Christian Faith!

\footnotetext{
${ }^{1}$ For example, in the arch sponsored by the tailors of Lisbon, King Philip II of Portugal was represented as King Solomon (Lavanha, 1622, 48-52).
} 
During the twelve tasks ordered by Eurystheus, the Theban demi-god reached distant lands, won prodigious trophies and defeated terrible monsters. Regarding the threats that in every age put in danger men, come up then the many-headed Hydra monster, the third daughter of Typhon and Echidna, the guardian of Arima "beneath the earth, a maiden immortal and ageless all days", and descendant of the terrible Medusa (Morford \& Lenardon, 2003, 154). The Hydra of Lerna was an awful beast with a hybrid body and several deadly and regenerative heads - seven, nine, fifty or more than one hundred heads, according to different classical writers ${ }^{1}-$, brought up and nourished by the goddess Hera to infest the region of the swamp of Amymone, near Lerna, Argolis. According to Hesiod [8th - 7th century BC] in Theogony, the Hydra bore Chimaira, another dreadful monster "who breathes fire not to be resisted"2.

This mythical figure may still have an older origin as it is connected with chthonic infernal deities, one of the reasons why she is always related to a dangerous dimension. Besides its terrifying aspect, reptilian traits and poisonous breath and blood (this last one used by Hercules as a powerful weapon against his own enemies), it was related to the evil and the domains of Hell. Beneath the waters where the monster lived, it was supposed to find the entrance to the Underworld ${ }^{3}$.

In a great part of ancestral religions of Egypt, Mesopotamia and Greece, the snake - don't forget that hydra means water-snake -, had a symbolism full of negative stereotypes, always associated to evil, danger and $\sin ^{4}$. For example, in Greek mythology the goddess Hera sent two snakes to kill Hercules in his cradle and god Apollo, who killed the Piton serpent in Delphos, to punish Laoocon's disobedience, sent also two snakes to kill both his sons.

According to the Book of Genesis, the shared first book of the Hebrew Tanakh and the Christian Old Testament, the snake was sent by Satan to tempt Eve to disobey God, the reason why He cursed her "above all livestock and all wild animals" (Genesis, 3, 14) ${ }^{5}$. In the New Testament the serpent appears again (Matthew, 23, 33). Nevertheless in the Surah As-Saaffat of the Quran,

\footnotetext{
${ }^{1}$ In the Fragment 443 attributed to Alcaeus and to Pseudo-Hyginus, the Hydra had nine heads, one of them immortal; following Simonides with fifty (Fragment 569); for Diodorus Siculus (Library of History, 4,11,5) and Ovid (Metamorphoses, 9, 69) one hundred heads. Only Pausanias mentioned one (Description of Greece, 2, 37, 4).

${ }^{2}$ The second labour of Hercules was mentioned by Hesiod (Theogony, 313-319); Alcaeus (Fragment 443); Strabo (Geography, 8, 6, 2-6); Pausanias (Description of Greece, 2,37,4/ 5,17,11); Diodorus (Library of History, 4,11,5); Ovid (Metamorphoses, 9, 69-192) and many others authors.

${ }^{3}$ The guardian of the Garden of the Hesperides, where Hercules stole a golden apple, was a hybrid serpent-dragon. In fact, in Hinduism and Buddhism a multi-headed snake Nagas is the commonly guardian of temples. The authors Morford and Lenardon mentioned also its similarity to the Indian hero Indra responsible for the death of the three-headed monster Visvarupa (Stanley, 2008, 45; Morford \& Lenardon, 2003, 539).

${ }^{4}$ But we cannot ignore the interpretation of the snake as a very common fertility symbol in PreColombian and Native American cultures and, even, in the ancient Greek religion as the symbol of the god of Medicine, Asclepius, that is a stock with a snake wrapped around it.

${ }^{5}$ There are other sparse references in Genesis, Exodus and Numbers biblical books.
} 
the central religious book of the Islam, the fruits of Zaqqum tree, eaten by the condemned people in Hell to intensify their torments, are compared to the hoods of the serpents (Surah, 37, 65).

Since Christian times, the Hydra monster assumed one of the several forms of evil, and then, during the Early Modern Period, when the Inquisition developed a determinative role in the Catholic societies, it became a way to identify the Protestants, Muslims, Jews and all heretic actions and deeds, understood as religious legacies from the ancient Paganism. They were the Catholic orthodoxy major threats!

According to this perspective, the most committed institutions who insisted to defend the Catholic Church could be compared to Hercules - the protector of the weak and in need (Silva, 2013, 20-21) -, which defeated its heretical opponents throughout the use of the sword and fire, like the Greek hero when he defeated the Hydra monster (Fig. 3).

Figure 3. "Honor: The Twelve Labors of Hercules (The Hhydra of Lerna)"

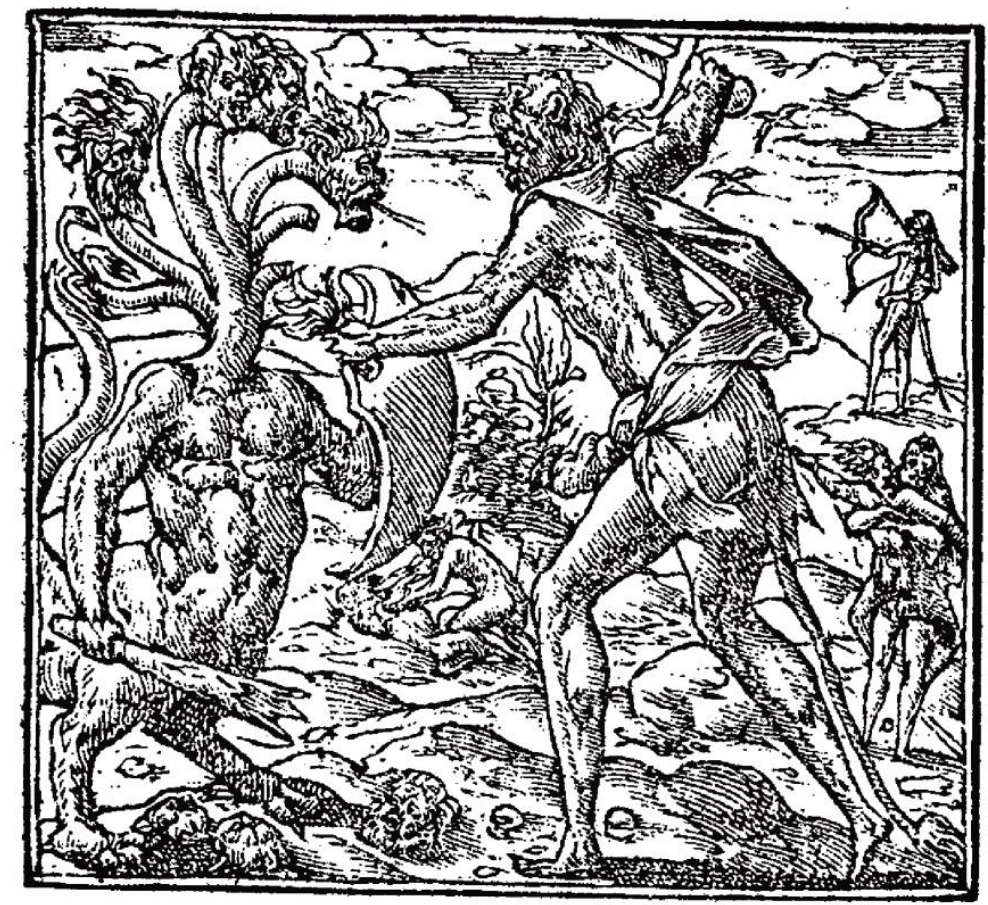

Source: Anonymous, 1558, Engrave M. Andrea Alciato. Toutes les emblems, Lyon, 169.

Once more we cannot ignore how the myth explains the way Hercules killed the Lernaean Hydra: after cutting its many heads, one by one, his nephew, Iolaus, using a burning torch, cauterized each severed wounded neck to avoid the growth of other two heads ${ }^{1}$. In the same way, to defend Catholic Faith, the Inquisition fought against heretical, infidel and schismatic movements using the blade of sword and the flame of the bonfires.

\footnotetext{
${ }^{1}$ But once Heracles won with the aid of Iolaus, Eurystheus declared the labor dishonest and instructed him another mission (Morford \& Lenardon 2003, 523).
} 
Always in close proximity with the Roman Church, the representatio majestatis image of the House of Habsburg monarchs was grounded over the Hercules lineage, the reason why his portrayal had gained a constant presence in the monuments erected in several cities to celebrate the remarkable royal entrance of King Philip II of Portugal / III of Spain [1578|1598-1621] in the Portuguese Kingdom, in 1619.

These majestic public festivals sceneries, composed mainly by ephemeral architectonic structures ornamented by persuasive artistic programs, achieved in Portugal the summit of outstanding exhibitions during the dynasty of the Spanish House of Habsburg, from 1580 to 1640. Defeated all his political opponents, King Philip II of Spain arrived at the Portuguese capital on June 29, 1581, for a magnificent public reception, to become then King Philip I of Portugal [1527|1580-1598]. Under his crown and scepter, the Iberians kingdoms and their main institutions - like the Inquisition -, since that moment, became a part of an empire on which the sun never sets (Pacheco, $[2011,1])^{1}$.

Raised under a deep religious education, King Philip II of Portugal during his reign was motivated not only to expand his Empire but he was also endeavored to extend the Realm of Heaven. Aided by the military conquests and religious successes of his father - remember the Battle of Lepanto, in 1571, and the creation of the American Inquisition tribunals in Mexico and Peru, in 1570 -, the monarch in the ancient world also reduced the Muslim and Ottoman influence within the Mediterranean and expanded the Catholic Faith in the new world, in the Atlantic, Pacific and Indic oceans ${ }^{2}$.

Ascending to the throne in 1598 the monarch announced his official visit to Portugal twenty one years later. Once again, the purpose was to gather the kingdom courts, where he should be presented to his yet unknown subjects and confirm their loyalty. But more important was to make the inheritor Prince swears to ensure the continuity of the Habsburg dynasty on the Portuguese throne.

Under supervision of the Viceroy, some Portuguese city councils decided, as a clear sign of joy receiving his distant King, to show his loyalty and obedience throughout the organization of a majestic royal festivity. Besides the several allegorical representations and symbolic signs dedicated to the majesty and grandeur of King Philip II, there were also present at the ephemeral monuments references to the King's piety and virtues. He was, in fact, the faithful Holy Roman Church defender and the devoted Tribunal of the Holy Office protector.

Established in Portugal in 1536, by King John III [1502|1521-1557], and nourished by his successors, the Holy Office of the Inquisition was a judicial institution based in religious purposes to serve not only the zealous needs of

\footnotetext{
${ }^{1}$ King Philip I of Portugal was son of the German Holy Roman emperor Charles V and of the Portuguese princess Elisabeth, daughter of King Emmanuel I and sister of King John III and King-Cardinal Henry.

${ }^{2}$ This Habsburg king reinforced also the Inquisition tribunals both in Portugal and in Spain and established the Tribunal in Cartagena de las Indias, Colombia.
} 
the Roman Church but also to attend the political ambitions of the Portuguese kings.

Under the protection of the royal crown and the papal tiara, arose a wellorganized institution responsible for the creation of a vigorous mechanism to maintain the purity of the Faith. Coveting the control and discipline of the society, heretic ideas were fought and protestant movements were chased during two hundred and eighty-five years of the Inquisition existing in Portugal. Following the inquisitorial instructions given out by the tribunals erected strategically in four cities - Coimbra, Évora and Lisbon, in Portugal, and Goa, in India -, a large number of faith agents inquired, persecuted and judged thousands of victims all over the Portuguese Empire, from Portugal and Mozambique to Brazil and Macau.

During the period of expansion of the inquisitorial activities, the General Council of the Inquisition concentrated efforts to reinforce the institution throughout the creation of the Familiars network in 1570, when the generalinquisitor, Cardinal Henry [1512|1578-1580], established the first rankings. With the approval of the inquisitors and the support of civil and religious institutions, the Familiars of the Holy Office, a group of civilian agents who cooperated with the Inquisition officers, in 1615, erected the brotherhood of Saint Peter of Verona [1206-1252], the first inquisitor martyrized in history ${ }^{1}$.

Reunited under the recent Brotherhood of Saint Peter of Verona, the Familiars, increasing their amount rapidly, had the perfect opportunity to get more public visibility, privileges and status, with the participation at the royal entrance of 1619 to welcome King Philip II of Portugal. But, despite the ignorance of the main responsible author for the artistic program of the Holy Inquisition ephemeral monument, one theme was repeatedly used: Hercules and the Hydra.

In the second Habsburg royal journey to Portugal, in 1619, the first reference that we can find related to the heresy fight using the myth of Hercules and the Hydra was in Elvas. At the Gate of Olivença, where the King was received, on May 10, was erected a structure built against that gateway. It was ornamented on the top with a painted panel representing the dead Hydra and a burning torch. Below the monster was the subtitle "HÆRESIS" and under the torch was "ZELVS FIDEI", meaning that fire destroys heresies. Based on the description of the official chronicler, we believe that the figure of Hercules was not present in the portrait (Lavanha, 1622, 2-4v).

The next stop of the royal itinerary was the city of Évora, where the King arrived on May 19. In this city, in the headquarters of a district Inquisition Tribunal, it was organized a public penitential procession and trial - the auto da fé -, event in which twelve persons and two baskets of forbidden books

\footnotetext{
${ }^{1}$ Beside the inquisitors, prosecutors, deputies and justice officers, integrated into the institution hierarchy as official members, the Holy Office had the support of a civil servant group, composed of laymen who assisted at the several activities and needs. Sometimes these agents fidalgos, artisans, merchants, farmers, soldiers and others - operated openly, in day light, seizing banned books or watching the accused in public penitential ceremonies (the autos da $f e$ ), other times they acted secretly, disguised and in a dissolute manner, with the purpose of finding and pointing out new offenders (Bethencourt, 2007, 77).
} 
were burned. But, strangely, there aren't any reports of the presence of ephemeral monuments ornamented with the myth of Hercules or the Hydra. Probably, the storm and the following rain that fell before, that prevented the festive arches conclusion and damaged the few raised, can justify its inexistence (LAVANHA 1622, 1-4v; Pacheco, [2013c, 2-4]).

To celebrate the King's presence at the empire's capital, the City Council of Lisbon organized the greatest and most majestic celebrative entrance on June 29, 1619. All over the city were erected thirty five architectonic and ephemeral structures, sponsored by local brotherhoods, national artisan's corporations and foreigner commercial and trader companies to emphasize and recognize the ruler's authority (Pacheco, [2013c, 5]).

For the first performance spectacle of the royal entrance, the Lisbon Customhouse, located near the royal quay, organized a dramatic theater to display King Philip II's most important political and religious actions. To illustrate the events, the artists chose an episode of the Titanomachy, presenting the King as Jupiter and the expelled Spanish Moorish communities and the defeated Turks as the Titans. Both defeated by the King, they were leaded to the Tartarus, identified by the Portuguese chronicler as Africa. In order to explain the whole scene, a set of Latin texts was placed on it. In the first, just above, was mentioned the Hydra and Giant Anteo - "NON CADERE ANTAEO, NON CRESCERE PROFVUIT HIDRAE" -, both defeated by Hercules. The second was complemented with a passage of Virgil, glorifying the King as a truthful fortress of God on Earth. And the last one, also in Latin, pointed out to the divine punishment that fell upon the Infidels expelled to Africa by the monarch (Lavanha, 1622, 10-12, 58).

However, the theme of the Hydra to represent the banished Muslims was neither new, not even original, once it was used already at the imperial entry organized to receive Charles V in Florence on April 29, 1552, to remember the conquest of Tunis conquest (Strong, 1984, 84). And, in the German arch erected in Lisbon for the royal entry of 1581, there was included, on a panel, the figure of Hercules chaining a seven-headed Hydra (Guerreiro, 1581, Chapt. VIII).

Ennobling the main streets and plazas, fountains and churches, the celebrative structures evoked the governance qualities and pious feelings of the monarch. After the ceremony of the city keys delivery and the cathedral celebrations, the King followed the itinerary until he reached the royal palace, in front of the Tagus River, where he stayed (Pacheco [2013c, 24]).

In this festive atmosphere, Hercule's portrait is to be found from one monument to another: on the top of the Lisbon traders' arch, in the presence of Jason, Theseus and Ulysses, the son of Zeus was evoked as the beast's slayer, entrusting the King's mission to eradicate the heretic monsters in his domains: "MONSTRORVM ALCIDES DOMITOR TIBI DICO PHILIPPE ORBVE VICTRICI PERFIDA MONTRA MANV"; on the Italian merchants' arch, one of the illustrative panels, showed Hercules defeating Cerberus and his three vices - gluttony, lust and greed - (Lavanha, 1622, 19v, 20, 33); and on the 
Flemish and German arches the "Christian Hercules" moves the Gibraltarian pillars (Lavanha 1622, 39v, 41v, 60v) ${ }^{1}$.

Trying to get the King favors and privileges, the Holy Inquisition Familiars of the Lisbon Tribunal sponsored also the construction of a celebrative monument. Actually the inquisitorial arch was erected and integrated at the main Royal Palace wall covering the major entrance, which reveals the pretension of the Inquisition agents to get close to the monarch (Fig. 4).

Figure 4. Arch of the Familiars of the Holly Office of Lisbon

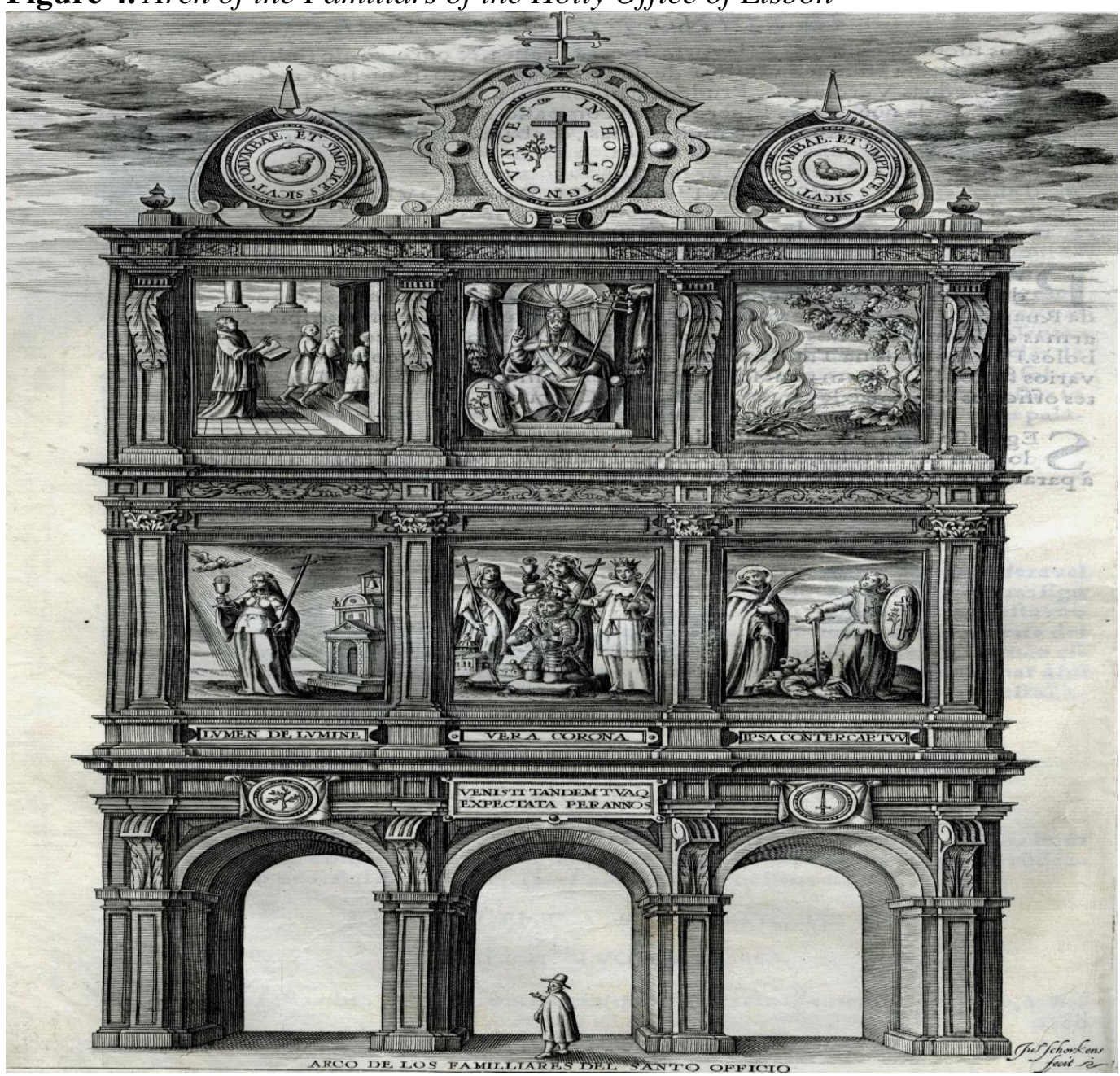

Source: Jan Schorkens, 1622, Engrave, João Baptista Lavanha. Viagem da Catholica Real Magestade del Rey D. Filipe II N.S. ao Reyno de Portugal, $52 v$.

\footnotetext{
${ }^{1}$ Hercules appears also at the Flemish monument supporting the world globe of Atlas. And Pizarro Gómez, in his study dedicated to all royal entries of King Philip II of Spain between 1548-1592, mentions thirty three figures of Hercules, between sculptures and paintings, at monuments erected in Antwerp, Binche, Bruges, Brussels, Malines Tournai (Belgium); Arras, Béthune (France); Genoa, Mantua, Milan (Italy); Dordrecht (Netherlands); Lisbon (Portugal); Benavente, La Coruña, Seville, Tarazona, Toledo (Spain) (Pizarro Gómez, 1999, 164-173, 182).
} 
Following the structural configuration of the ancient Roman triumphal monuments, the celebrative arch of the Inquisition Familiars, erected in the King's honor, the only one in an exclusive event among all the European Inquisitions, should call the attention to the main sponsor and present the doctrinal mission of the inquisitorial institution. Embedded into the palace façade, the arch was composed by three sections, like the monuments sponsored by the Flemish traders and the local candle makers.

Probably elaborated also by João Baptista Lavanha [c.1550-1624], once he is considered the main person responsible for the royal entrance planning, influenced by Juan de Herrera's [1530-1597] projects for the royal entry of 1581 (Pacheco, [2013b, 6]), the artistic program revealed a strong visual impact of the austere Mannerist aesthetic style, in full accordance to the doctrinal Trent Council guidelines.

The first segment corresponded to the ground floor entrance and it had three similar porticos. The central one, the honor door for the King's passage, had in the top a passage of Virgil's [70-19 BC] Aeneid, a speech between Aeneas and Anchises in the Underworld (Aeneid, VI, 687-691; Lavanha, 1622, 53v, 54, 58), evoking King Philip II's of Portugal/III of Spain ancestral lineage with the hero of Troy, the last descendant of Aeneas, like his grandfather, Charles I of Spain, had claimed years before ${ }^{1}$. Over the other porticos were put the Inquisition symbols, an olive tree branch, to express mercy (left), and the sword, to express justice (right).

On the top, over the central panel, was the Inquisition coat of arms surrounded by the motto "IN HOC SIGNO VINCES", adopted also by King John III, the founder of the Portuguese Holy Office Tribunal. At the flanks there were two discs decorated by a snake biting its tail, trapping a dove, with the text of Mathew's Gospel $(16,10)$ : “[PRVDENTES SICVT SERPENTES] ET SIMPLICES SICVT COLVMBAE" (Lavanha, 1622, 53).

Between both sections, it was a delightful Faith theater sponsored by the Inquisition Familiars. In order to show an inspiring catechetical program to the spectators, it was used a dramatic apparatus scenario composed by a coherent iconographic set of six paintings, independent but linked two by two, each one explained by individual biblical passages (Lavanha, 1622, 53; Pacheco, [2013c, 27]).

Another illustrative example of the mythological Lernaean monster was described by the Portuguese chronicler Lavanha and etched by the Flemish printmaker Jan Schorkens [c.1595-1630?] over the drawing of the Portuguese artist Domingos Vieira Serrão [c.1570-1632]. In Lavanha's description it could be seen the exploration of the symbolism of the defeat of the Hydra, in a clear allusion to the decisive role fulfilled by the Inquisition and the King himself ${ }^{2}$.

\footnotetext{
${ }^{1}$ About this matter see the work of Marie Tanner, The Last Descendant of Aeneas: The Hapsburgs and the Mythic Image of the Emperor, New Haven/ London, Yale University Press, 1993.

${ }^{2}$ The book dedicated to the Royal Entry of 1619 - Viagem da Catholica Real Magestade del Rey D. Filipe II - had two editions, published firstly in Spain, in 1621, and then in Portugal, in the year of 1622 .
} 
While the first group show the salvation and forgiveness of the Church towards their lost sheep, the next one illustrates the Crown and Tiara alliance, at the moment that the virtue and pious King was being crowned by the allegorical figures of the Holy Church, Faith and Justice, with the Pope's blessing at the upper scene. Nevertheless, despite the royal foundation of the Inquisition Tribunal, in Portugal and in Spain, the institution blazon in the shield was put near the figure of the pope and not the King.

The last two paintings presented the responsibility and duty of the Inquisition to persecute and punish heresies. The lower picture was adorned with the patron of the Lisbon Familiars of the Holy Office, the Dominican Saint Peter of Verona (could be Iolaus?), pointing out to the defeated Hydra and saying a Latin passage from Genesis (3:15): "IPSA CONTERET CAPVT TVVM". The terrible monster denounced by the saint is a direct allusion of the mission of Familiar agents of the Holy Office to chase and oppress all heretical forms (Figs. 5-6) (Lavanha, 1622, 53).

Figure 5. Detail of Arch of the Familiars of the Holy Office of Lisbon: Inquisition Eradicate the Heresies

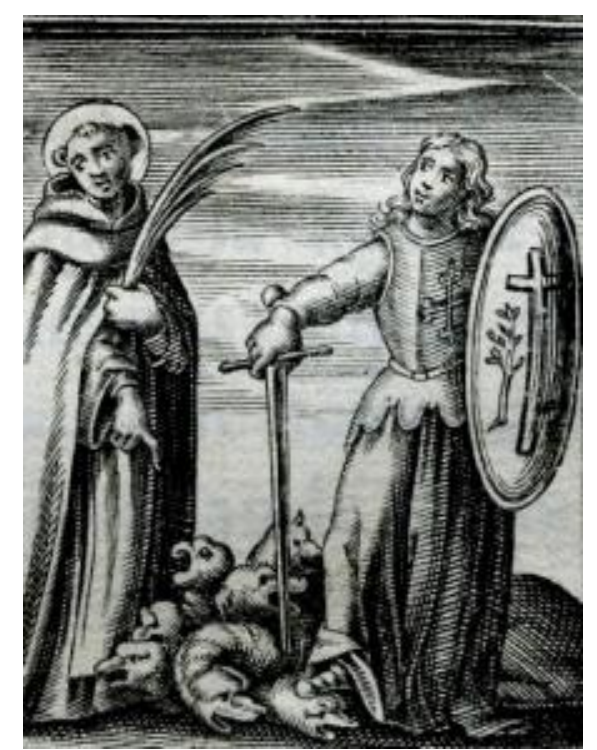

Source: Jan Schorkens, 1622, Engrave João Baptista Lavanha. Viagem da Catholica Real Magestade del Rey D. Filipe II N.S. ao Reyno de Portugal. Lisboa, 52v. 
Figure 6. "GOD OR RELIGION: Fake Religion",

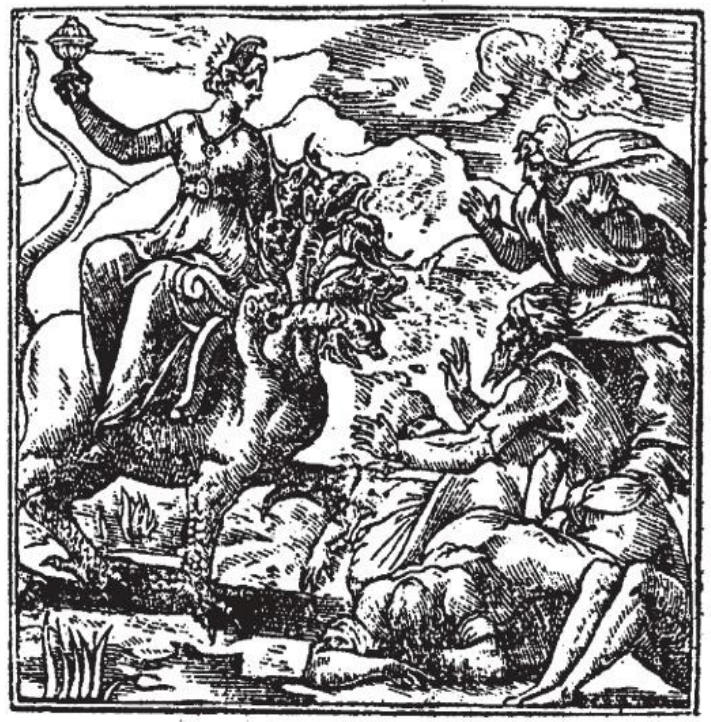

Source: Anonymous, 1558, Engrave M. Andrea Alciato. Toutes les emblems. Lyon, 24.

Dressed with inquisitorial insignias, the Dominican Cross, also repeated on the shield, a feminine figure represents allegorically the Inquisition - Hercules -, in the moment when she is piercing with a sword the Apocalypse sevenheaded serpent, identified by the chronicler himself as the Lernaean Hydra (Lavanha, 1622, 53). But if this picture reveals the use of Greek mythology, the other, just above, shows clearly a biblical influence. While in the corner flourishes the fertile and good Lord's vineyard, on the other side, the dry and sterile branches are burned: "QVIA IN VITE NON SVNT (Jeremiah: 14, 4) (Fig. 8) (Lavanha, 1622, 53-v).

Figure 7. "Love: Against Love"

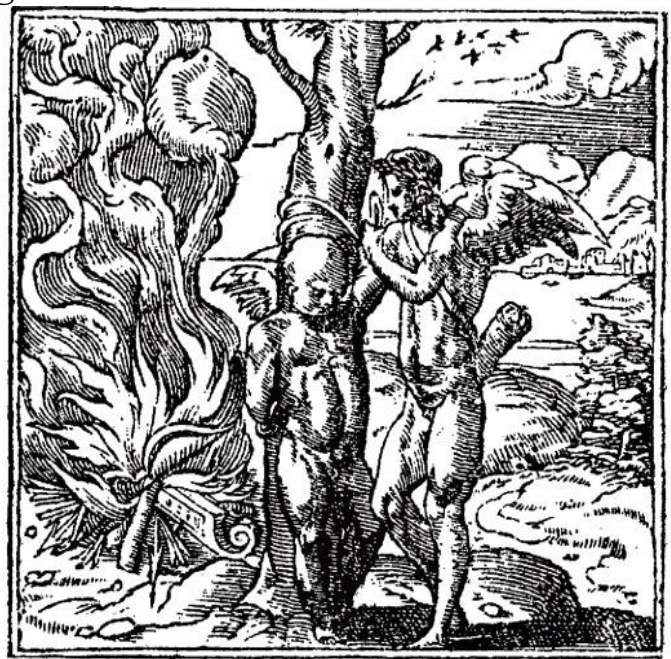

Source: Anonymous, 1558, Engrave M. Andrea Alciato. Toutes les emblems. Lyon, 141. 
Figure 8. Detail of Arch of the Familiars of the Holy Office of Lisbon: The Good and the Bad Vineyards

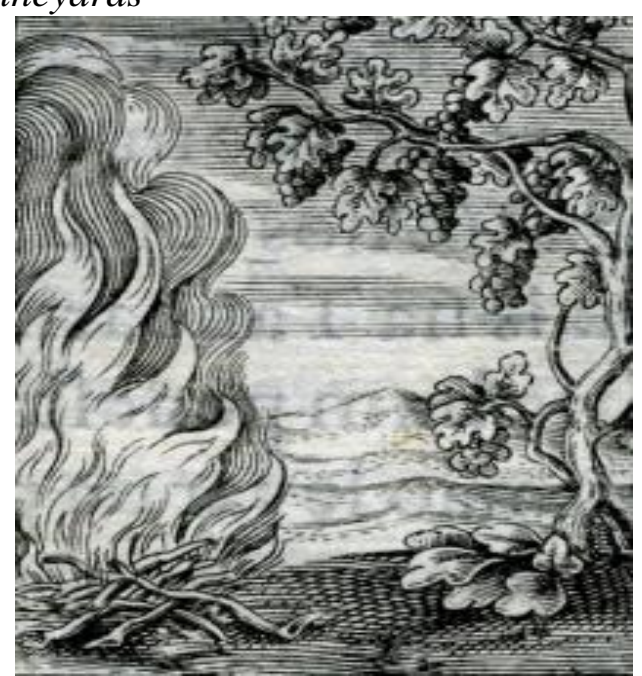

Source: Jan Schorkens, 1622, Engrave João Lavanha. Viagem da Catholica Real Magestade del Rey D. Filipe II N.S. ao Reyno de Portugal. Lisboa, $52 v$.

Figure 9. "PRUDENCE: The Prudent avoid the Wine"

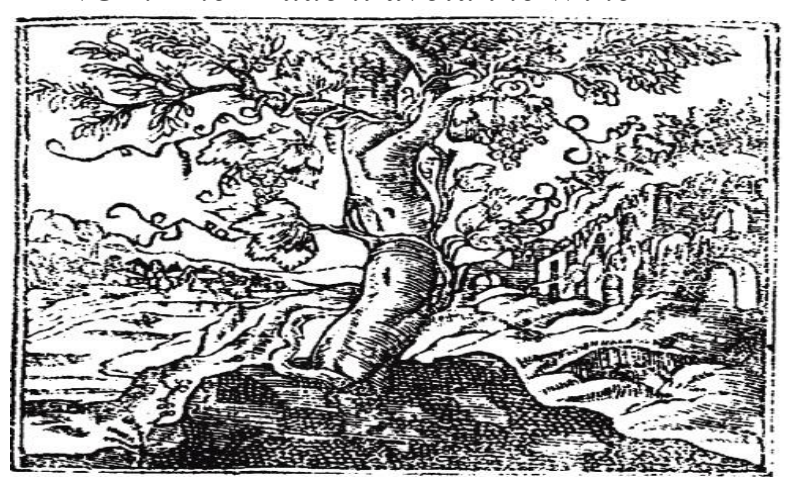

Source: Anonymous, 1558, Engrave M. Andrea Alciato. Toutes les emblems. Lyon, 46

Unfortunately we do not have evidence enough to prove whether some of these emblems integrated in the current literary works influenced the creative programs of the seventeenth century artists appointed to the construction and decoration of the arch (Figs. 6, 7, 9). Neither the extent of the importance of Hercules killing the Hydra sixteenth century engraves, such as those that integrate the collection of the British Museum, in London, used as inspirational models (Figs. 10, 11). 
Figure 10. "Hercules Killing the Hydra of Lerna"

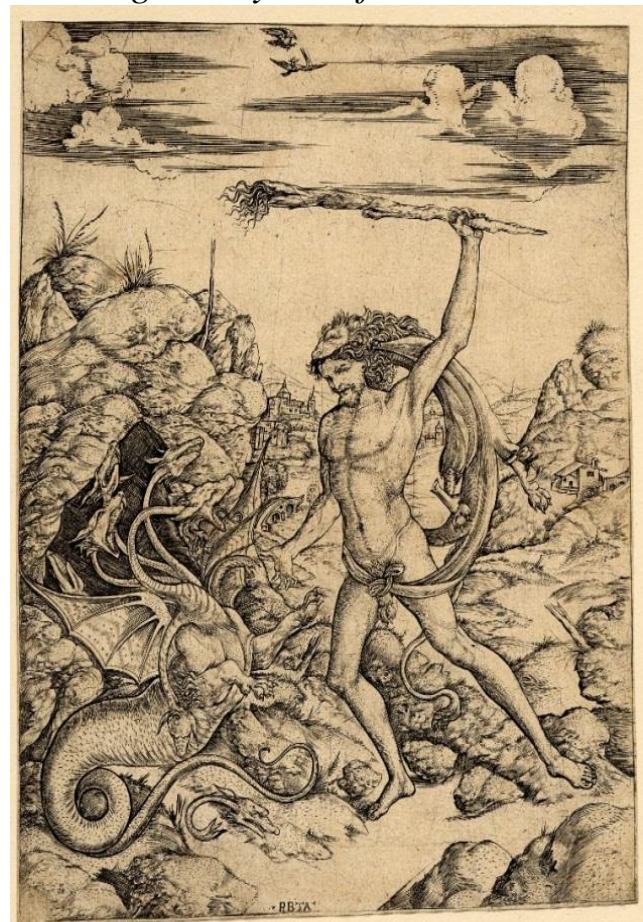

Source: After Antonio Pollaiuolo, c. 1500-1520, EngraveThe British Museum, London, United Kingdom

Figure 11. Hercules Killing the Hydra of Lerna

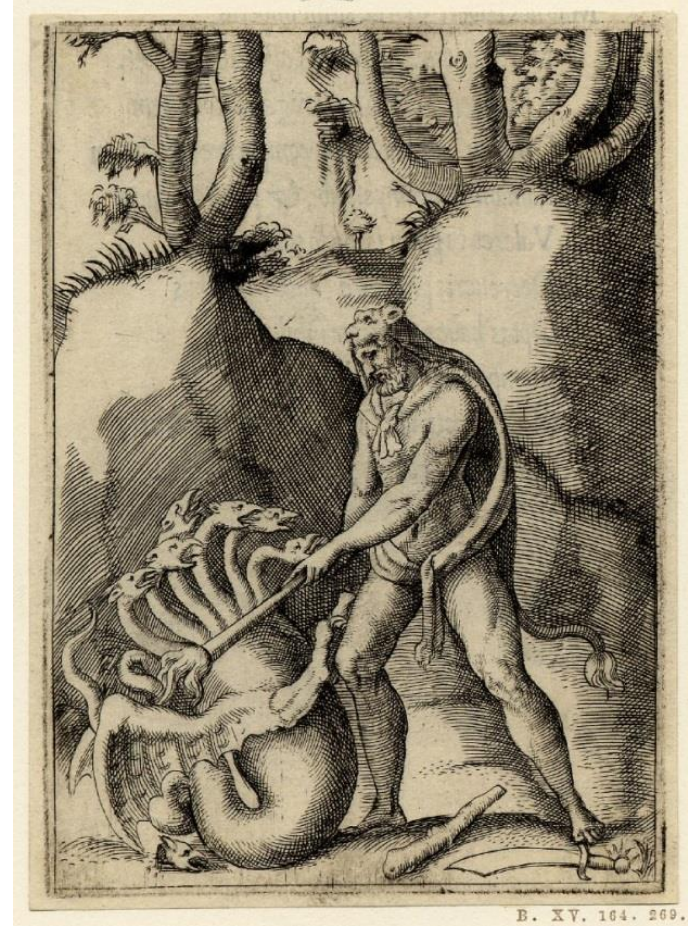

Source: Anonymous, 1555 Engrave The British Museum, London, United Kingdom 
Since the Late Antique period until the present, but especially during the Renaissance, and then with the Baroque, there were many artists generations that shaped, with different techniques and different materials, the fight between the heroic Hercules and the terrible Hydra.

Proceeding to a general analysis of all representations reproduced in the structures erected along the royal itinerary, it is clear the appropriation of Greek mythology symbolism by the Inquisition to express the institution mission ideals, to the King, to his royal entourage and to people present. Using strategically some signs on the royal entrance arches and monuments to express an idealistic message, the Holy Office remembers the commitment of King Philip II not only as the Church's faithful defender, but also as the main protector of the inquisitorial institution.

Like in the myth, when Hercules destroyed the terrible monster with a sword and fire, in the beginnings of the seventeenth century the Inquisition assumed the same responsibility to cut and burn all the heresies that threatened the Roman Church, assuming the triumph of good over evil.

Nowadays, in an epoch without heroes, but with monsters and new inquisitions, the Hydra of Lerna still is flourishing within the Western culture ${ }^{1}$. Besides many generations of artists and writers, scientists see their work also influenced by it: in astronomy, it served to baptize the constellation of the Hydra in the equatorial region of the southern sky (created by Hera after the fight with Hercules near the constellation of Cancer); and in biology, to name a species of freshwater hydroid polyp, the Hydra Viridissima (that capture its own food through the deadly and poisonous long members, with the "ability to regrow itself from cut-off parts" (Morford \& Lenardon, 2003, 770)).

Greek myths are, in fact, a celebration of Mankind, revealing our strengths and weaknesses, our worst fears and our secret desires (Kirk, 2005, 8). Even today, this ancient legacy, forged around the Mediterranean melting pot, influences contemporary lifestyle and culture, more present then we can imagine.

\section{References}

Alciato, M. A., 1558. Toutes les emblems. Lyon.

Bethencourt, F., 2007. The Inquisition. A global history, 1478-1834. Cambridge: University Press.

Blázquez, J.M., 2000. Mitos clásicos en la pintura moderna. Anales de Historia del Arte, 10, pp. 247-281.

Cardim, P., 2008. Felipe III, la Jornada de Portugal y las Cortes de 1619. La Corte de Felipe III y el Gobierno de la Monarquia Católica (1598-1621), IV. Madrid: Fundácion Mapfre, pp. 900-946.

Castro, J. Machado de, 1810. Descripção Analytica da execução da real estatua equestre do Senhor Rei Fidelissimo D. José I. Lisbon: Imprensa Regia.

\footnotetext{
${ }^{1}$ In the last Marvel movie - Captain America: The Winter Soldier (2014) - Hydra is a world-wide subversive and terrorist organization.
} 
Ferro, M., 2013. A interseção do paradigma tassiano na épica portuguesa do Barroco: O caso exemplar de Vasco Mouzinho de Quevedo Castelbranco - O Discurso sobre a Vida e Morte de Santa Isabel (1597), Afonso Africano (1611) e Triumpho del monarca Philipo tercero en la felicissima entrada en Lisboa (1619)". Veredas: Revista da Associação Internacional de Lusitanistas, p. 23.

Frazer, M., 1974. Hades Stabbed by the Cross of Christ. Metropolitan Museum Journal. 9, pp. 153-161.

Guerreiro, A., 1581. Das festas que se fizeram na cidade de Lisboa na entrada del Rey D. Philippe primeiro de Portugal. Lisbon: Printed by Francisco Correia.

Huon, A., 1956. Le thème du Prince dans les entrées parisiennes au XVI ${ }^{\mathrm{e}}$ siècle. Les Fêtes de la Renaissance, Paris : Éditions du Centre National de la Recherche Scientifique, pp. 21-28.

Jacquot, J., 1956. Joyeuse et Triomphante Entrée. Les Fêtes de la Renaissance, Paris: Éditions du Centre National de la Recherche Scientifique, pp. 9-19.

Kirk, S., 2005. Greek Myths. Tales of Passion, Heroism, and Betrayal. San Francisco: Chronicle Books.

Lavanha, J. B., 1622. Viagem da Catholica Real Magestade del Rey D. Filipe II N.S. ao Reyno de Portugal E rellação do solene recebimento que nelle se lhe fez $S$. Magestade a mandou escrever por João Baptista Lavanha sev cronista mayor. Madrid: Printed by Thomas Iunti.

Medeiros, F., 2013. Monstrorum domitori. Emblematic and allegorical representations of the Herculean tasks performed by Joseph I, king of Portugal (1750-1777). Hercules: a hero for all ages. Hercules conference 2013. Leeds: University of Leeds, p. 7.

Morford, M. P. O. and Lenardon, R. J., 2003. Classical Mythology. New York/Oxford: Oxford University Press.

Pacheco, M. P. D., 2013a. Celebrate Empire. The presence of the Portuguese possessions at the royal entry of King Philip I in Lisbon (1581). European Courts in a Globalized World. Lisbon: PALATIUM - Court Residences as Places of Exchange in Late Medieval and Early Modern Europe 1400-1700/ Centro de História de Além Mar, p. 28.

Pacheco, M. P. D., 2013b. «De vossa Real presença desejada»: Uma apologia político-alegórica a D. Filipe II de Portugal. Crise e Rutura Peninsular. III Congresso SEEPLU. Cáceres: SEEPLU/ Universidad de Extremadura. Servicio de Publicaciones, pp. 179-212.

Pacheco, M. P. D., 2013c. «Do rocio do Ceo». O arco triunfal do Santo Ofício da Inquisição de Lisboa na entrada régia de D. Filipe II em 1619, III Encontro Internacional de Jovens Investigadores de História Moderna. Évora: CIDEHUS, p. 34 .

Pacheco, M. P. D., 2014. Palaces on the edge of the Atlantic: The architectural reformation and the space ritualization of the Portuguese royal residences during the reign of Phillip I of Habsburg (1580-1598) [pdf]. The Habsburgs and their Courts in Europe, 1400-1700. Between Cosmopolitism and Regionalism. Vienna: European Science Foundation/PALATIUM/ Österreichische Akademie der Wissenschaften, pp. 55-71. Available at: PALATIUM E-BOOK.

Pizarro Gómez, F. J., 1999. Arte y espectáculo en los viajes de Felipe II. Madrid: Ediciones Encuentro.

Ripa, C., 1593. Iconologia. Roma.

Ripa, C., 1645. Iconologia. Veneza.

Ripa, C., 1709. Iconologia. London. 
Vol. 1, No. $1 \quad$ Pacheco: Greek Mythology at the Service of the Portuguese...

Rodrigues, J. D., 2011. The Flight of the Eagle: an Island Tribute to the Universal Iberian Monarchy at the end of the sixteenth century, e-journal of Portuguese History, 9 (2), p. 34.

Silva, M. de Fátima, 2013. Da violência à civilização. Hércules, o Super-Homem da Antiguidade. Humanitas, LXV, Coimbra, pp. 9-26.

Soares, E., 1948. Dicionário de Iconografia Portuguesa, II. Lisbon: Instituto de Alta Cultura.

Stanley, J. W., 2008. Snakes: objects of Religion, Fear and Myth. Journal of Integrative Biology, 2(2), pp. 42-58.

Strong, R., 1984. Art and Power. Renaissance Festivals 1450-1650. Berkeley-Los Angeles: University of California Press.

Vivanti, C., 1967. Henry IV, the Gallic Hercules. Journal of the Warburg and Courtauld Institutes, 30, London, pp. 176-197. 